\title{
PENINGKATAN HAK GUNA BANGUNAN YANG HABIS MASA BERLAKUNYA MENJADI HAK MILIK ATAS TANAH
}

\author{
Werdi Haswari Puspitoningrum \\ Program Studi Magister Kenotariatan PPS Unisma \\ Jalan Mayjen Haryono Nomor 193 Malang \\ Email:werdimknuim@gmail.com
}

\begin{abstract}
Abstrak
Status hukum HGB yang sudah berakhir masa berlakunya menurut peraturan perundang-undangan adalah kembali kepada status hukum asal hak atas tanah tersebut, yakni kembali menjadi tanah negara atau tanah dengan hak-hak tertentu yang dikuasai oleh subyek hukum pribadi atau badan hukum perdata.Tanah berstatus HGB yang habis masa berlakunya tidak dapat ditingkatkan menjadi hak milik. Meskipun demikian, dalam peraturanperundang-undangan telah disediakan dua carayang memungkinkan pemegang HGB yang jangka waktunya berakhir tetapmenjadi pemegang HGB, yaitu melalui perpanjanganhak dan pembaharuan hak. Cara mengajukan permohonan peningkatan status tanah dari HGB yang sudah habis masa berlakunya menjadi hak milik adalah dengan mengajukan kembali HGB yang telah berakhir masa berlakunya melalui perpanjanganhak atau pembaharuan hak.
\end{abstract}

Kata Kunci: peningkatan, hak guna bangunan, hak milik

\begin{abstract}
The legal status of the HGB which has expired according to legislation is returning to the legal status of origin of the land rights, namely returning to state land or land with certain rights controlled by subject to personal law or civil legal entity. Land with a status of HGB which expires cannot be increased to ownership rights. Nevertheless, in the legislation two ways have been provided which allow HGB holders whose term expires to become HGB holders, namely through extension and renewal of rights. The way to apply for an increase in the status of land from HGB that has expired into ownership is by re-submitting the HGB which has expired through extension or renewal of rights.
\end{abstract}

Keywords: improvement building rights, right of ownership 


\section{PENDAHULUAN}

Di dalam Undang-Undang Dasar 1945 Pasal 33 menyatakan bahwa. Seluruh wilayah Indonesia adalah satu kesatuan tanah air seluruh rakyat Indonesia yang bersatu. Dalam hal ini, bumi, air, dan ruang angkasa juga termasuk kekayaan alam yang terkandung di dalamnya. Dengan demikian kekayaan alam yang ada di Negara kita tidak semata-mata digunakan menjadi hak milik pribadi, tetapi digunakan untuk kemakmuran rakyat Indonesia.

Amanat pasal 33 Undang-undang 1945 dapat di maknai hak-hak atas tanah yang dimaksud untuk menggunakan tanah, bumi, dan air serta ruang angkasa yang ada di atasnya sekedar digunakan langsung untuk kepentingan yang berhubungan dengan penggunaan tanah sesuai dengan ketentuan yang berlaku. Selain hak-hak atas tanah juga ditentukan hak-hak atas air dan ruang angkasa. Dalam Pasal 33 ayat 3 diterangkan bahwa Negara tidak memiliki tanah, melainkan memberikan wewenang kepada Negara untuk:

1. Mengatur, menyelenggarakan peruntukan, penggunaan, persediaan,dan pemeliharaan bumi, air, ruang angkasa.Dalam kewenangannya untuk mengatur mengenai hak-hak yang berkaitan dengan peruntukan, penggunaan dan persediaan bumi, air dan ruang angkasa serta melaksanakan peraturan tersebut.

2. Menentukan, mengatur, hubungan-hubungan hukum antara orangorang dengan bumi, air dan ruang angkasa. Bahwa tanah mempunyai arti penting dalam kehidupan manusia.

Sejak disahkan Undang-Undang Nomor 5 tahun 1960 tentang Peraturan Dasar Pokok-Pokok Agraria, yang lebih dikenal dengan UUPA mempunyai tujuan yang mengatur tentang pertahan di Indonesia, Adapun tujuan lahirnya UUPA adalah sebagai berikut :

1. Untuk meletakkan dasar-dasar bagi penyusunan Hukum Agraria Nasional

2. Untuk meletakkan dasar-dasar, mengadakan kesatuan dan kesederhanaandalam hukum pertanahan; dan

3. Untuk meletakkan dasar-dasar untuk memberikan kepastian hukummengenai hak-hak atas tanah bagi rakyat seluruhnya ${ }^{1}$

Sejak lahirnya UUPA, maka terjadi perubahan fundamental terhadap hukum agraria di Indonesia, yaitu terwujudnya suatu keseragaman hukum tanah nasional. Perubahan tersebut bersifat mendasar atau

${ }^{1}$ Undang-undang nomor 5 tahun 1960, tentang Peraturan Dasar Pokok-pokok 
fundamental, karena baik mengenai sruktur perangkat hukumnya, mengenai konsepsi yang mendasarnya, maupaun isinya, harus sesuai dengan kepentingan rakyat Indonesia serta memenuhi pula keperluannya menurut permintaan zaman. ${ }^{2}$ Obyek hukum tanah adalah hak-hak penguasaan atas tanah. Dan hak-hak penguasaan tersebut dibagi dua, yaitu sebagai lembaga hukum dan sebagai hubungan konkret.

Meningkatnya kebutuhan masyarakat menyebabkan para pemegang Hak Guna Bangunan (HGB) merasa perlu untuk meningkatkan status hak atas tanahnya menjadi Hak Milik, terutama atas tanah untuk rumah tinggal. Karena secara yuridis, menurut Undang-undang Nomor 5 Tahun 1960 tentang Peraturan Dasar Pokok-pokok Agraria, yang lazim disebut Undangundang Pokok Agraria (UUPA) hak milik atas tanah di samping memiliki sifat turun temurun (tidak mengenal masa berlaku) juga memiliki kedudukan (status) hukum yang paling tinggi (terkuat dan terpenuh) dibandingkan dengan hak-hak atas tanah lainnya, termasuk HGB yang ada masa habis berlakunya. Oleh karena itu, pemegang HGB umumnya merasa perlu meningkatkan haknya menjadi hak milik atas tanah.

Persoalannya apakah HGB yang habis masa berlakunya dapat ditingkatnya menjadi Hak Milik? Berangkat dari latar belakang tersebut di atas, makalah hasil penelitian ini bertujuan untuk mengetahui dan menganalisis: (1) bagaimana status hukum HGB atas tanah yang sudah berakhir masa berlakunya; (2) apakah tanah dengan status HGB yang telah berakhir masa berlakunya dapat ditingkatkan menjadi hak milik.

\section{METODE PENELITIAN}

Penelitian adalah suatu kegiatan yang dilaksanakan dengan suatu sistematika, metodologi ilmiah dengan tujuan untuk memperoleh sesuatu yang baru atau asli dalam usaha memecahkan suatu masalah yang setiap saat dapat timbul di masyarakat. ${ }^{3}$

Jenis penelitian yang digunakan dalam penelitian ini adalah yuridis normatif. Menurut soerjono soekanto penelitian yuridis normatif adalah penelitian hukum yang dilakukan dengan cara meneliti bahan pustaka atau data sekunder sebagai bahan dasar untuk diteliti dengan cara mengadakan penelusuran terhadap peraturan-peraturan dan literatur-literatur yang

${ }^{2}$ Boedi Harsono, Hukum Agraria Indonesia, Sejarah Pembentukan UUPA, Isi dan Pelaksanaanya, jilid 1Hukum Tanah Nasional. (Jakarta: Djambatan, 2003), hal 1.

${ }^{3}$ Sukandarrumidi, Metodologi Penelitian: Petunjuk Praktis untuk Peneliti Pemula, (Yogyakarta: Gajah Mada University Press, 2006), hal.111 
berkaitan dengan permasalahan yang diteliti ${ }^{4}$ dengan menggunakan pendekatan peraturan perundang-undangan (statute approach) dan pendekatan komparatif (comparative approach). Jenis bahan hukum yang digunakan dalam penelitian ini adalah jenis bahan hukum primer yaitu bahan hukum berupa peraturan perundang-undangan dan bahan hukum sekunder yaitu bahan hukum yang diperoleh dari bahan pustaka, antara lain meliputi buku-buku hukum, jurnal atau hasil penelitian, literatur, peraturan perundang-undangan, dan sumber lainnya yang berkaitan dengan penelitian ini. Dalam penelitian ini penulis akan mengunakan teknik analisis kualitatif yaitu bahan hukum yang diperoleh, kemudian disusun secara sistematis, menyeluruh dan lengkap serta terintegrasi untuk mencapai kejelasan masalah yang akan dibahas. ${ }^{5}$

\section{PEMBAHASAN}

\section{Status Hukum Hak Guna Bangunan Yang Habis Masa Berlakunya}

Legalitas kepemilikan tanah atau properti menjadi hal yang sangat penting dan perlu untuk dibuktikan. Adapun kasus yang masih banyak terjadi adalah kepemilikan tanah atau properti adalah status tanah yang masih sebatas sertifikat Hak Guna Bangunan (HGB). Tentunya, pemegang hak atas tanah pasti ingin memiliki status kepemilikan yang lebih kuat. Untuk itu, perlu meningkatkannya menjadi sertifikat Hak Milik.

Bagaimanakah jika Hak Guna Bangunan yang kita miliki habis masa berlakunya, apa konseksensi hukumnya atas tanah Hak Guna Bangunan yang habis apa bisa diperpanjang kembali atau jatuh kepada negara.

Ada beberapa pasal dan peraturan menteri yang berkenaaan dengan status hukum tentang hak guna bangunan yang habis masa berlakunya yang perlu dianalisis, antara lain sebagai berikut :

1. Keputusan Menteri Negara Agraria/Kepala Badan PertanahanNasional Nomor 9 Tahun 1997Tentang Pemberian Hak Milik Atas Tanah Untuk RumahSangat Sederhana (RSS) dan Rumah Sederhan (RS).

Pada bagian Umum Pasal I keputusan ini disebutkan bahwa yang dimaksud dengan:

1) Hak Guna Bangunan Induk adalah Hak Guna Bangunan atas tanah yangkemudian dipecah menjadi bidang-bidang tanah yang lebih kecil atausebagiannya dipisahkan untuk didaftar sebagai bidang tanah tersendiri.

2) Perubahan hak adalah penetapan Pemerintah mengenai penegasan

${ }^{4}$ Soerjono Soekanto dan Sri Mamudji, Penelitian Hukum Normatif(Suatu Tinjauan Singkat), (Jakarta: RajawaliPers, 2001), hal.13-14

${ }^{5}$ Boy. S. Sabarguna, Analisis Data pada Penelitian Kualitatif, (Jakarta: UI Press, 2006), hlm.16. 
bahwasebidang tanah yang semula dipunyai dengan Hak Guna Bangunan, atas permohonan pemegang haknya menjadi tanah negara dan sekaligusmemberikan tanah tersebut kepadanya dengan Hak Milik.

3) Hak pengelolaan adalah hak menguasai dari Negara yang kewenangan pelaksanaannya sebagian dilimpahkan kepada pemegangnya.

Yang perlu digarisbawahi dalam pasal tersebut adalah pasal 1 ayat (1) dan (2), artinya ayat (1) dapat dimaknai bahwa seorang pengembang yang membeli tanah dengan setatus hak milik yang akan dipergunakan untuk perumahan maka setatus tanah tersebut diturunkan menjadi hak guna bangunan dan dijual atau dipecah menjadi lebih kecil-kecil dan menjadi bagian tersendiri dan mempunyai nama pemegang sendiri sampai diajukan perubahan hak dari hak guna bangunan menjadi hak milik. Atau bisa dimaknai tanah dengan sertifikat HGB juga diperoleh dari pembelian rumah baru dari developer. Karena developer adalah badan hukum yang tidak diperbolehkan memiliki tanah dengan status Hak Milik, walaupun pada awalnya developer membeli tanah dengan status Hak Milik dari masyarakat. Dalam prosesnya, tanah dengan status SHM tersebut harus diturunkan dulu haknya menjadi Hak Guna Bangunan baru dilakukan jual beli dan balik nama ke atas nama developer.

Sedangkan untuk ayat (2) dapat diartikan bahwa perubahan yang dengan tanah seperti yang dijelaskan dalam ayat (1) tersebut dapat dimohonkan perubahan hak yang status dulunya dari Hak Guna Bangunan dalam prosesnya menjadi tanah Negara, setelah itu diajukan menjadi hak milik. Dengan kata lain,developer menjual rumah dengan status Hak Guna Bangunan kepada konsumen dan mempersilahkan konsumen sendiri yang mengurus peningkatan hak tersebut. Status kepemilikan sertifikat Hak Milik adalah status kepemilikan paling kuat tanpa campur tangan atau kemungkinan dipunyai oleh pihak lain. Cara merubah HGB menjadi SHM dilakukan di Kantor Pertanahan di wilayah tempat lokasi lahan tersebut berada.

2. Keputusan Menteri Negara Agraria/Kepala Badan Pertanahan NasionalNomor 1 Tahun 1998TentangPerluasan Pemberian Hak Milik Atas Tanah Untuk RSS/RS.

MenurutKeputusan Menteri Negara Agraria / Kepala Badan PertanahanNasional tersebut terdapat dalam pasal 2 yang berbunyi sebagai berikut :

1) Memperluas pemberian Hak Milik atas tanah untuk RSS/RS menurut KeputusanMenteri Negara Agraria/ Kepala Badan Pertanahan 
Nasional Nomor 9 Tahun 1997,sehingga meliputi tanah Hak Guna Bangunan untuk RSS/RS di atas tanah Negara dantanah Hak Pengelolaan kepunyaan Warga Negara Indonesia yang telah habis jangkawaktunya.

2) Pendaftaran Hak Milik atas tanah RSS/RS yang Hak Guna Bangunannya sudah habissebagaimana dimaksud ayat (1) dilakukan dan diproses sesuai ketentuan dalamKeputusan Menteri Negara Agraria/Kepala Badan Pertanahan Nasional Nomor 9Tahun 1997.

Ketentuan pasal 2 ini dapat dimaknai bahwa baik ayat (1) dan (2) memberikan keluasaan dan penafsiran bahwa HGB atas tanah negara bisa diajukan perubahan hak meskipun habis masa berlakunya.

Peraturan Menteri Negara Agraria/Kepala Badan Pertanahan NasionalNomor 9 Tahun 1999TentangTata Cara Pemberian dan Pembatalan Hak AtasTanah Negara dan Hak Pengelolaan, Paragraf 3Tata Cara Perpanjangan Jangka waktu dan Pembaharuan Hak Guna Bangunan.

Peraturan Pemerintah Republik IndonesiaNomor 40 Tahun 1996 TentangHak Guna Usaha, Hak Guna Bangunan danHak Pakai Atas Tanah Pasal 36 dan Pasal 37 tentang hapusnya Hak Guna Bangunan yang berakhir masa berlakunya yang berbunyi sebagai berikut :

Pasal 36 menentukan:

(1) Hapusnya Hak Guna Bangunan atas tanah Negara sebagaimana dimaksud dalam Pasal 35mengakibatkan tanahnya menjadi tanah Negara.

(2) Hapusnya Hak Guna Bangunan atas tanah Hak Pengelolaan sebagaimana dimaksud dalam Pasal35 mengakibatkan tanahnya kembali ke dalam penguasaan pemegang Hak Pengelolaan.

(3) Hapusnya Hak Guna Bangunan atas tanah Hak Milik sebagaimana dimaksud dalam Pasal 35 mengakibatkan tanahnya kembali ke dalam penguasaan pemegang Hak Milik.

Selanjutnya, Pasal 37 menentukan:

a. Apabila Hak Guna Bangunan atas tanah Negara hapus dan tidak diperpanjang atau tidak diperbaharui, maka bekas pemegang Hak Guna Bangunan wajib membongkar bangunan dan benda-benda yang ada di atasnya dan menyerahkan tanahnya kepada Negara dalam keadaan kosong selambat-lambatnya dalam waktu satu tahun sejak hapusnya Hak Guna Bangunan.

b. Dalam hal bangunan dan benda-benda sebagaimana dimaksud dalam ayat (1) masih diperlukan, maka kepada bekas pemegang hak diberikan ganti rugi yang bentuk dan jumlahnya diatur lebih lanjut dengan Keputusan Presiden. 
c. Pembongkaran bangunan dan benda-benda sebagaimana dimaksud dalam ayat (1) dilaksanakan atas biaya bekas pemegang Hak Guna Bangunan.

d. Jika bekas pemegang Hak Guna Bangunan lalai dalam memenuhi kewajiban sebagaimana dimaksud dalam ayat (1), maka bangunan dan benda-benda yang ada di atas tanah bekas Hak Guna Bangunan itu dibongkar oleh Pemerintah atas biaya bekas pemegang Hak Guna Bangunan.

Dari keempat peraturan dan pasal tersebut di atas yang mengatur tentang Status Hukum Hak Guna Bangunan yang habis masa berlakunya penulis dapat menyimpulkan bahwa:

1. Berkaitan dengan terbatasnya jangka waktu danHak Guna Bangunan, dalam peraturanperundang-undangan telah disediakan dua carayang memungkinkan pemegang Hak GunaBangunan yang jangka waktunya berakhir tetap menjadi pemegang Hak Guna Bangunantersebut, yaitu:

a) Pertama melalui perpanjangan hak,

b) Kedua melalui pembaharuan hak.

2. Perpanjangan hak adalah penambahan jangkawaktu berlakunya sesuatu hak tanpa mengubahsyarat-syarat dalam pemberian hak tersebut.Sedangkan pembaharuan hak adalah pemberianhak yang lama kepada pemegang hak atas tanahyang telah dimilikinya dengan Hak GunaBangunan sesudah jangka waktu hak tersebutatau perpanjangannya berakhir (Pasal 1 angka 6dan 7 PP 40/1996).

3. Perpanjangan Hak Guna Bangunan (HGB), yang dilaksanakan baik sebelum maupun setelah berakhirnya HGB.

4. Oleh karena Sertipikat HGB telah berakhir masa berlakunya, maka hak atas tanah kembali kepada Negara (dikuasai oleh Negara). Sementara Pemegang Hak atas tanah telah meninggal dunia, maka hak atas tanah jatuh kepada ahli waris. Prosedurnya bukan perpanjangan hak atas tanah, tetapi 'permohonan hak atas tanah'

5. Hak Guna Bangunan yang habis masa berlakunya harus diperbaharui atau ditingkatkan status kepemilikannya menjadi hak milik sebelum masa belakunya habis dan jika Hak guna bangunan yang habis masa belakunya tidak di perbaharui maka setatus tanah tersebut akan kembali kepada setatus asal dari tanah tersebut, jika awalnya dari tanah negara akan kembali kepada negara dan apabila tanah tersebut dari tanah pengelolaan akan kembali menjadi ke pemegang hak pengelolaan dan jika hak milik maka kembali kepada pemegang hak milik dan sesuai dengan perjanjiannya. Hal ini sesuai dengan Pasal 36 PP 40/1996 yang berbunyi:

(1) Hapusnya Hak Guna Bangunan atas tanah Negara sebagaimana 
dimaksud dalam Pasal 35 mengakibatkan tanahnya menjadi tanah Negara.

(2) Hapusnya Hak Guna Bangunan atas tanah Hak Pengelolaan sebagaimana dimaksud dalam Pasal 35 mengakibatkan tanahnya kembali ke dalam penguasaan pemegang Hak Pengelolaan.

(3) Hapusnya Hak Guna Bangunan atas tanah Hak Milik sebagaimana dimaksud dalam Pasal 35 mengakibatkann tanahnya kembali ke dalam penguasaan pemegang Hak Milik.

6. Di dalam ketentuan Pasal 27 ayat (1) Peraturan Pemerintah Nomor 40 Tahun 1996 menyebutkan, bahwa permohonan perpanjangan jangka waktu Hak Guna Bangunan diajukan selambat-lambatnya dua tahun sebelum berakhirnya jangka waktu Hak Guna Bangunan tersebut, Sedangkan menurut Pasal 41 Peraturan Menteri Negara Agraria/Kepala Badan Pertanahan Nasional Nomor 9 Tahun 1999 tentang Tata Cara Pemberian dan Pembatalan Hak Atas TanahNegara dan Hak Pengelolaan, dinyatakan bahwa permohonan perpanjangan jangka waktu HakGuna Bangunan diajukan oleh pemegang hak dalam "tenggang waktu"2 (dua) tahun, sebelum berakhirnya jangka waktu hak tersebut. Keterangan di atas memperlihatkan, bahwa PPNomor 40 Tahun 1996 menggunakan kalimatlugas "selambat-lambatnya". Sedangkan PMNA/KBPN Nomor 9 Tahun 1999 memakai istilah"tenggang waktu", yang menyiratkan maknalebih longgar. Dengan adanya 2 (dua) istilah berbeda yang dipergunakan menyangkut jangkawaktu pengajuan permohonan perpanjangan Hak Guna Bangunan, maka dapat menimbulkanpenafsiran serta implikasi yang berbeda di dalamprakteknya. Hal ini akan sedikit banyakberpengaruh terhadap terselenggaranyakepastian hukum.Di dalam kenyataannya masih banyak pemegang Hak Guna Bangunan (HGB) yang telah habis masa berlakunya tidaksegera melakukan perpanjangan Hak GunaBangunan (HGB) tersebut. Hal tersebut dikarenakan ketidaktahuan para pemegang HakGuna Bangunan (HGB) tersebut bahwa sertifikatHak Guna Bangunan (HGB) yang telah habismasa berlakunya harus segera diperbarui. ${ }^{6}$

\section{Peningkatan Hak Guna Bangunan Yang Dapat menjadi Hak Milik}

Pendaftaran tanah adalah rangkaian kegiatan yang dilakukan oleh Pemerintah secara terus-menerus, berkesinambungan dan teratur, meliputi

${ }^{6}$ Fhamilla Mur Ambika Jurnal Pelaksanaan Perpanjangan Hak Guna Bangunan (HGB) Yang Telah Habis Masa Berlakunya Berdasarkan Peraturan Pemerintah Nomor 40 Tahun 1996, Fakultas Hukum,Universitas Atmajaya Yogyakarta. 
pengumpulan, pengolahan, pembukuan, dan penyajian serta pemeliharaan data fisik dan data yuridis, dalam bentuk peta dan daftar, mengenai bidangbidang tanah dan satuan-satuan rumah susun, termasuk pemberian surat tanda bukti haknya bagi bidang-bidang tanah yang sudah ada haknya dan Hak Milik atas satuan rumah susun serta hak-hak tertentu yang membebaninya (PP Nomor 24 Tahun 1997 Tentang Pendaftaran Tanah)

Pendaftaran tanah dilaksanakan berdasarkan asas sederhana, aman, terjangkau, mutakhir dan terbuka, untuk itu pendaftaran tanah bertujuan:

(1) Untuk memberikan kepastian hukum dan perlindungan hkum kepada pemegang hak atas suatu bidang tanah, satuan rumah susun dan hakhak lain yang terdaftar agar dengan mudah dapat membuktikan dirinya sebagai pemegang hak yang bersangkutan.

(2) Untuk menyediakan informasi kepada pihak-pihak yang berkepentingan termasuk Pemerintah agar dengan mudah dapat memperoleh data yang diperlukan dalam mengadakan perbuatan hukum mengenai bidangbidang tanah dan satuan-satuan rumah susun yang sudah terdaftar.

(3) Untuk terselenggaranya tertib administrasi pertanahan .

Secara teoritis, perubahan hak adalah penetapan Pemerintah mengenai penegasan bahwa sebidang tanah yang semula dipunyai dengan suatu hak atas tanah tertentu, atas permohonan pemegang haknya, menjadi tanah Negara dan sekaligus memberikan tanah tersebut kepadanya dengan hak atas tanah jenis lainnya”. (Pasal 1 angka 11 Peraturan Menteri Negara Agraria/Kepala Badan Pertanahan Nasional Nomor 3 Tahun 1999).

Dengan demikian secara teori sebenarnya peningkatan status Hak Guna Bangunan menjadi Hak Milik terdiri dari dua proses yang bersambungan yaitu: 1). Pelepasan Hak Guna Bangunan dari pemegangnya kepada Negara hingga menjadi tanah Negara; dan 2). Pemberian Hak Milik atas tanah Negara dari Pemerintah kepada mantan pemegang Hak Guna Bangunan dimaksud. Keputusan Menteri Negara Agraria/Kepala Badan Pertanahan Nasional Nomor 6 Tahun 1998 tentang Pemberian Hak Milik AtasTanah Untuk Rumah Tinggal, terdapat dalam Pasal 1 dan Pasal 3.

Hal ini selaras dengan Keputusan Menteri Negara Agraria/Kepala Badan PertanahanNasional Nomor 9 Tahun 1997Tentang Pemberian Hak Milik Atas Tanah Untuk Rumah Sangat Sederhana (RSS) dan Rumah Sederhana (RS), pasal 2 dan pasal 3 yang berbunyi sebagai berikut:

Pemberian Hak Milik bagi tanah untuk RSS dan RS. Dengan keputusan ini:

a. Hak guna bangunan atas tanah untuk RSS dan RS di atas tanah Negara, termasukdi atas tanah Hak Pengelolaan, kepunyaan perseorangan warga negara Indonesia, atas permohonan pemegang hak atau kuasanya diubah menjadi HakMilik; 
b. Tanah untuk RSS dan RS diatas tanah hak Pengelolaan kepunyaan perseorangan warga negara Indonesia yang belum dipunyai dengan Hak Guna Bangunandiberikan dengan Hak Milik.

c. Untuk perubahan Hak Guna Bangunan menjadi Hak Milik sebagaimana dimaksud pada ayat (1) dan pendaftarannya pemohon wajib membayar uang administrasi kepada Negara sebesar Rp. 10.000; (sepuluh ribu rupiah) dan sumbangan pelaksanaan landreform sebesar Rp. 5.000; (lima ribu rupiah) danbiaya pendaftaran sesuai ketentuan Peraturan Kepala Badan PertanahanNasional Nomor 2 Tahhun 1992.

Sebagai penguat dari peraturan menteri yang lain, Peraturan Pemerintah Republik IndonesiaNomor 24 Tahun 1997TentangPendaftaran Tanah,bagian keduaobyek pendaftaran tanah tercantum dalam Pasal 9 ayat (1) yang berbunyi sebagai berikut :

(1) Obyek pendaftaran tanah meliputi :

a) Bidang-bidang tanah yang dipunyai dengan hak milik, hak guna usaha, hakGuna bangunan dan hak pakai;

b) Tanah hak pengelolaan;

c) Tanah wakaf;

d) Hak milik atas satuan rumah susun;

e) Hak tanggungan;

f) Tanah Negara.

Peraturan Pemerintah Republik IndonesiaNomor 40 Tahun 1996Tentang Hak Guna Usaha, Hak Guna Bangunandan Hak Pakai Atas Tanah,Bagian KeduaTanah Yang Dapat Diberikan Dengan Hak Guna Bangunan, Pasal 21 yang berbunyi sebagai berikut :

Tanah yang dapat diberikan dengan Hak Guna Bangunan adalah:

a) Tanah Negara;

b) Tanah Hak Pengelolaan;

c) Tanah Hak Milik.

Untuk Hak Guna Bangunan yang tidak bisa diajukan peningkatan atau pembaharuan hak menjadi hak milik adalah RUKO (Rumah dan Toko) dan RUKAN (Rumah dan Kantor) kenapa karena Rumah Toko (RUKO) dan Rumah Kantor (RUKAN) tidak termasukdalam pengertian rumah tinggal sebagaimana dimaksud KeputusanMenteri Negara Agraria/Kepala Badan Pertanahan Nasional Nomor6 Tahun 1998 Dengan demikian, jika bentuk bangunan maupun di dalam IMB-nya tertulis bahwa bangunan tersebut merupakan Ruko, maka tidak dapat diajukan peningkatan haknya menjadi Hak Milik. Walaupun pemiliknya adalah WNI Perorangan. Karena memang keistimewaan tersebut hanya diberikan bagi rumah tinggal, dengan filosofi bahwa rumah tinggal memang diperuntukkan bagi yang bersangkutan untuk memiliki selamanya. 
Akan tetapi kadang ada Ruko yang berstatus hak milik, kalau kita mengkaji Keputusan Menteri Negara Agraria/Kepala Badan Pertanahan Nasional Nomor 6 Tahun 1998 tidak mungkin bisa menjadi hak milik, hal ini terjadi biasanya sebelum pembangunan Ruko tersebut dilakukan, tanahnya sudah berstatus Hak Milik, dan kemudian pemiliknya membangun ruko di atas tanah tersebut. Jadi, bukan berasal dari HGB yang ditingkatkan menjadi Hak Milik.

\section{KESIMPULAN}

Status hukum Hak Guna Bangunan atas tanah yang sudah berakhir masa berlakunya menurut peraturan perundang-undangan adalah kembali kepada status hukum asal hak atas tanah tersebut, yakni kembali menjadi tanah negara atau tanah dengan hak-hak tertentu yang dikuasai oleh subyek hukum perorangan atau badan hukum perdata. Tanah berstatus Hak Guna Bangunan yang habis masa berlakunya tidak dapat ditingkatkan menjadi hak milik. Meskipun demikian, dalam peratura $\mathrm{n}$ perundang-undangan telah disediakan dua carayang memungkinkan bagi pemegang Hak Guna Bangunan yang jangka waktunya berakhir tetapmenjadi pemegang Hak Guna Bangunan, yaitu melalui perpanjangan hak dan pembaharuan hak. Perpanjangan Hak Guna Bangunan dilaksanakan baik sebelum maupun setelah berakhirnya Hak Guna Bangunan.

\section{DAFTAR PUSTAKA}

\section{Buku dan Jurnal}

Boedi Harsono,2003, Hukum Agraria Indonesia, Sejarah Pembentukan UUPA, Isi dan Pelaksanaanya, jilid 1 Hukum Tanah Nasional.(Jakarta: Djambatan).

Boy. S. Sabarguna, 2006, Analisis Data pada Penelitian Kualitatif, (Jakarta: UI Press).

Fhamilla Mur Ambika JurnalPelaksanaan Perpanjangan Hak Guna Bangunan (HGB) Yang TelahHabis Masa Berlakunya Berdasarkan Peraturan PemerintahNomor 40 Tahun 1996, Fakultas Hukum,Universitas Atmajaya Yogyakarta.

Sukandarrumidi, 2006, Metodologi Penelitian: Petunjuk Praktis untuk Peneliti Pemula, Yogyakarta: Gajah Mada University Press.

Soerjono Soekanto dan Sri Mamudji, 2001, Penelitian Hukum Normatif (Suatu Tinjauan Singkat), Jakarta: RajawaliPers.

\section{Peraturan Perundang-undangan}




\section{Jurnal HUKUM dan KENOTARIATAN \\ Volume ZNomor Z Agustus 2018}

Undang-undang Nomor 5 Tahun 1960 tentang Peraturan Dasar Pokokpokok Agraria, yang lazim disebut Undang-undang Pokok Agraria (UUPA)

Peraturan Pemerintah Republik IndonesiaNomor 40 Tahun 1996TentangHak Guna Usaha, Hak Guna Bangunan danHak Pakai Atas Tanah

Peraturan Pemerintah Republik IndonesiaNomor 24 Tahun 1997TentangPendaftaran Tanah

Peraturan Menteri Negara Agraria/Kepala Badan Pertanahan Nasional Nomor 9 Tahun 1999 tentang Tata Cara Pemberian dan Pembatalan Hak Atas TanahNegara dan Hak Pengelolaan

Keputusan Menteri Negara Agraria/Kepala Badan Pertanahan NasionalNomor 1 Tahun 1998TentangPerluasan Pemberian Hak Milik Atas Tanah Untuk RSS/RS.

Keputusan Menteri Negara Agraria/Kepala BadanPertanahan Nasional Nomor 6 Tahun 1998 tentang Pemberian Hak Milik AtasTanah Untuk Rumah Tinggal 